\title{
Equity provision equal-pay for work of equal-value implementation within South African State-Owned Enterprise (SOE)
}

\author{
Lesiba Langa \\ Seugnet Bronkhorst \\ University of Johannesburg, APK Campus, South Africa
}

\author{
Keywords \\ Employment Equity Act, Equal pay assessment, State-owned enterprise, Semi-structured \\ interview, \\ Reflexivity and Interpretative Phenomenological Analysis
}

\begin{abstract}
Purpose of the research: The purpose of the study is to determine how a state-owned enterprise in South Africa deploys equal pay for work of equal value. The research setting and environment where the investigation takes place are located in a state-owned enterprise (SOE) called ZYD.

Research methodology: An inductive research approach is used with qualitative research for primary data and for secondary numeric data. The research includes a population sample of eight participants who are involved in the primary research data collection. In addition, a company finance report is analysed for the secondary data collection. Equally, some qualitative primary research data are analysed quantitatively in order to make sense of the data (Saunders, Lewis $\mathcal{E}$ Thornhill, 2012:165).

Results/findings:The study confirms that implementing equal pay has a financial implication attached to it, insignificant as it is. Uncoordinated confirmations for promoting equal pay exist. Lack of a comprehensive approach to equal pay encompasses the majority concerns. The study shows how important it is for the organisation to have all essential pillars in place and in sync with one another, which lagged in this case. With the essential pillars in place and in sync, a robust pay equity system/model, which is supported by policy, will be leveraged and initiated as a business imperative, promoting open communication and empowerment about equal pay (Bradshaw, et al., 2017:3). Vignettes have been constructed and highlighted in order to bring alive the participants' voices within the researcher's interpretations of meaning.

Practical implications and Conclusions: South African researchers and researchers across the globe have shown little interest to explore the racial pay discrimination situation; they have constantly researched gender-based pay inequity instead. This should be reason enough to have future research studies focusing on pay equity irrespective of race, gender or disability.
\end{abstract}

Introduction

The purpose of the study s to determine how a state-owned enterprise in South Africa deploys equal pay for work of equal value. Equal pay for work of equal value received much attention in recent years due to the important implications for employees and challenges to employers. The promotion of gender equality and equal pay for work of equal value are currently high on the agenda of various countries (Adelekan \& Bussin, 2018:3). Equal pay for work of equal value includes work that is the same, substantially the same and work with same value with other work (Bussin \& Smit, 2015:28). Equal pay for work of equal value is the provision made within the Employment Equity Act 55 of 1998 in South Africa which was introduced in August 2014 (Ebrahim, 2016:5).

While the origins of equality provision resulted from gender discrimination in most businesses around the world (Bussin \& Smit, 2015:28, Laubscher \& Gilfillan, 2015:3), South Africa's context on unfair discrimination and exclusion of pay inequality are apparent among the various race groups. Statistics South Africa (2017:1) states that South Africa's economic climate is complex, as it is characterised by high unemployment ratios, the most unequal country in terms of distribution of country wealth, high skills challenges, low productivity levels, low economic growth, low inflation ranging from three to six percent, and high prices. Therefore, this situation necessitates a special need to have equality provision on pay. Blau and Kahn (2007:7), supported by Arulampalam, Booth and Bryan (2007:164) stress that without the 
provision of equal pay, the determination of remuneration is primarily based on supply and demand for work and labour.

Vartiainen (2001:19) argues that employers have too much uncontrollable power over salary determination. The determination of remuneration, which is based on supply and demand of labour, perpetuates low and unequal pay that is driven and fuelled by capitalist approaches that undervalue gender and race groups previously excluded from the mainstream economics (Adelekan \& Bussin, 2018:3). As a result, unfair discrimination practices arise from employers as they attempt to decompose what part of pay inequity constitutes unfair discrimination. In addition, Biltagy (2014:18) stresses that while the labour market discrimination often responsible for the unexplained wage gap, the challenge might be on unobserved and unmeasured variables in worker and job aspects. Vartiainen (2001:19) further states that the decomposition is evident in the gender pay gap of Finland over the years where pay gap explanations have been made, using variables such as educational background and choice of low paying jobs.

According to Sandberg (2016:1) it is acknowledged that the equal pay for work of equal value provision has started in August 2014, and that the Labour Relations Act has prohibited unfair discrimination in remuneration practices prior to the dawn of democracy for South Africans in 1994. Notwithstanding the long period stated, the fact that pay inequality is still dominant in South Africa shows the reluctance to implement equal pay for work of equal value in favour of unequal pay for equal value of work (Blau \& Kahn, 2007:7).

\section{Literature review}

The research environment is the ZYD company which is an energy-production business. The company has recently celebrated its $96^{\text {th }}$ year of existence and it operates across South Africa. It has 48500 employees comprising permanent and temporary employees who work in all nine provinces with its head-office in Sunninghill, Gauteng province. The skills within the company range from technical, engineering, procurement and sourcing, logistics, strategic planning, production, human resources, finance, information technology, horticulture, property and facility management. The large size of the organisation, the variety of the skills and many position profiles give rise to comparisons in terms of similar jobs, substantially similar jobs and jobs with comparable value as per the equal pay provision cited on the internal job evaluation of ZYD.

ZYD uses a job evaluation system to evaluate and grade all jobs that management requires, irrespective of whether these are permanent or temporary jobs. The job evaluation system is known as Tuned Assessment of Skills and Knowledge (TASK) as cited on its internal job evaluation.

The recruitment and selection policies of ZYD state that every employee and potential employee can apply for an advertised position, irrespective of colour, race, gender, disability, location of the job and where the candidate comes from as long as they meet the minimum requirements of the job description. A salary structure, which is aligned to the graded jobs, exists as per the job levels (TASK grades 04 to 18). The structure comprises a minimum and maximum of the scale per grade with six different salary zones between the minimum and the maximum, giving rise to discriminatory pay for work of equal value, whether it be fair or unfair.

\section{The Concept of Equal Pay for Work of Equal Value}

Almost five years after the equal pay provision has been in place companies still struggle with salary discrepancies, with allegations of unfair discriminatory practices based on gender, racial and/or disability (Rospabe, 2002:185). Rospabe (2002:185) regards the turning of the revolution of discrimination in South Africa as the period between 1993 and 1999 during which discrimination in labour participation has decreased, whereas wage and occupational discrimination have increased. What is required, according to Adelekan and Bussin (2018:3), is also a reduction in occupation and wage discrimination in order to allow a good representation of the South African workforce across all occupational jobs as well as of improved wages.

The meaning of 'work of equal value', as per Section 6(4) of the Employment Equity Act, states the following (Scheepers, 2014:16): 
Work carried out by an employee is observed to be the same or identical or interchangeable to the work of another employee within the same employer.

Work carried out by an employee is observed to be substantially the same or sufficiently similar compared to that of another employee within the same employer, such that these jobs can be considered to be reasonably the same irrespective of whether identical or interchangeable.

Work carried out by an employee is observed to be of the same value as work of another employee within the same employer; however, doing a different job, as both jobs are evaluated and accorded the same value.

Purpose of Equal Pay for Work of Equal Value

Pay equity

Promoting equal opportunities and fair treatment.

Implementing affirmative action intended to redress the ills within the employment experienced by designated groups.

2. Eliminating unfair discrimination in the workplace

3. Addressing identified pay gaps

4. Annual employee remuneration report

5. Organisational report on pay differentials

The Pillars of Equal Pay

Countries have adopted equal pay differently and at different times. Through globalisation and digitalisation that disregard formal boundaries, people in different countries have started sharing information, including equal pay and pay discrimination information. Such international efforts include the League of Nations and the International Labour Organization. The latter was founded at the Paris Peace Conference held in 1919.

According to Watkins (2019:1068), the workforce has increased exponentially due to the workplace environment that is accommodative and cherishes and protects the rights of women. The U.S. Congress continues to use its law-development power to adopt equal pay legislation to the new employee landscape (Watkins, 2019:1051). The evolvement of equal pay according to Figart (2000:1) and Vartiainen (2001:19), with efforts to erase explicit pay discrimination are observed, yet it has reproduced new gender and equal pay unfair practices. Trade unions in South Africa, and internationally in 1919, seek to explore extreme and seemingly unattainable improvements to this piece of legislation, such that pay equity becomes a reality sooner than later (Dube, 2017:13).

The establishment of the ILO, through various equal pay conventions and declarations, intends that party members adopt and comply with, promote and protect this legislation (Tufarolo, 2016:321). The international conventions and declarations are important cornerstones of equal pay, as they seek to make companies comply, promote and protect the equal pay provision (Dube, 2017:14). Based on the lead of the Equal Pay Act, legislation in various countries has significantly improved and led to today's equal pay for work of equal value statutory framework (Watkins, 2019:1051).

When dealing with equal pay case claims, a possible remedy that can be awarded to the employer is to increase the applicant's remuneration to the level of the comparator; thus, achieving pay equity without reducing the comparator's remuneration (Oliphant, 2015:14). Such provision is included in the Canadian Human Rights Act of 1978, where it is provisioned expressively that the employer may not reduce the remuneration of a comparator in order to eliminate discrimination and achieve pay equity (Laubscher \& Gilfillan, 2015:40).

The South African Constitution states that any international agreement that has been enacted into law by national legislation becomes law in South Africa unless it is inconsistent with the Constitution. It further states that when courts interpret any legislation, every court must prefer any reasonable interpretation of the legislation that is in consistent with international law on any alternative interpretation that is inconsistent with international law (Section 233).

Considering the above obligations and commitments, South Africa has signed to be a member of the ILO. Therefore, South Africa is obliged to align with agreements made internationally (Dube, 2017:17). It is evident that international law plays a significant role in South African courts, as South Africans are protected locally by international law. Where the law is approved internally and ratified locally or not 
ratified locally, there is no local legislation enacted to give effect to the member's obligations (Dube, 2017:17). It is this International Labour Organization Convention 100 on remuneration that South Africa has ratified on 30 March 2000.

The Constitution protects the rights and dignity of everyone in South Africa. Before 1994, the Labour Relations Act of South Africa, Section 2(1)(a) of Schedule 7 has prohibited unfair discrimination in remuneration practices. Individuals who have been aggrieved by discriminatory practices in the workplace should use this legislation to demand recourse. The Act stipulates that an unfair labour practice means any unfair labour act or omission that arises between an employee on any arbitrary ground, including but not limited to race, gender, sex, ethnic or social origin, colour, sexual orientation, age or disability (Dube, 2017:18). Accordingly, individual rights have already existed and been protected by this piece of legislation (Laubscher \& Gilfillan, 2015:2).

The Employment Equity Act 55 of 1998 has been enacted to give effect to the promotion of equality in the workplace where individuals with equal pay grievances who sought to challenge employer remuneration practices could use this piece of legislation in their claims. The purpose of this Act is to achieve equity in the workplace by promoting equal opportunities and fair treatment in employment through eliminating unfair discrimination and implementing affirmative action measures to redress the disadvantages in employment experienced by designated groups. In addition, this Act stipulates that no person may discriminate unfairly, directly or indirectly, against an employee in any employment policy or practice on a variety of grounds, among others, race, gender, disability and culture (Dube, 2017:18). Laubscher and Gilfillan (2015:2) assert that the enactment of the Employment Equity Act has resulted in the Labour Relations Act, Section 2(1)(a) of Schedule 7 being repealed, as its purpose is included in the Act itself.

The definition of equal pay, according to the legislative scope includes employment policy on remuneration, contractual terms and conditions, which employers and employees would use in dealing with claims at the courts (Dube, 2017:18). Equal pay for work of equal value was evidenced in the case of Hayward versus Cammell Laird where a claim was put forth and found to be successful in comparing a female cook with three joiners, two painters and an insulation engineer. In the past, women could only make claims for equal pay with a comparable male where work was similar or substantially similar. This case was the first to be adjudicated following the enactment of the Pay Equity Act Amendment Regulations, which came into effect from 1 January 1984. Therefore, it had far-reaching implications, broadening the equal pay context.

Variables Influencing Pay Equity/Inequity

1. Pay transparency

The employee making a claim would obtain information about the comparator remuneration from the comparator who can decline the request and the employee could then request the employer to provide the comparator's remuneration information. Pay transparency is an essential aspect to pay equity, and since employers strive to eliminate barriers to pay equity, they should remove this clause from the conditions of employment contract so that pay discussions for everyone are facilitated with ease (Khovera, 2012:47).

\section{The power to negotiate pay}

Causevic (2018:751) and Khovera (2012:47) are of the opinion that employers have a habit of using a previous salary slip to observe to gauge the increase level, project a ten percent attraction fee and that is the remuneration that is offered to the candidate employee. This is the reason why employers and employees negotiate on remuneration, and, in turn, it causes pay inequity, as various people differ in negotiating (Bosch, 2015:4). The interest level to negotiate also differs. People who are often excluded economically such as Africans, women and people living with disabilities strive to be included in the economy. Therefore, they display very low behaviours of demanding and aggressive traits in pay negotiations (Watkins, 2018:1078). Negotiating for pay should be disbanded, as it is the cause for pay inequity and have for the past period sustained the pay gap (Brown, 2017:489). 


\section{Reactions to pay equity/inequity}

Difference in pay expectations by individuals plays a crucial role in the racial or gender-based wage gap (Khovera, 2012:27). Due to the social comparison individuals with similar attributes and opinions are relevant and influential to one another (Suls et al., 2002:159). Gender socialisation leads to a construction of a society where individuals are put in specific blocks or social roles, such that men and women receive positive reinforcement for behaving in ways that are regarded appropriate to their gender, as well as receive negative feedback when behaving like the opposite sex (Smith \& Rogers, 2000:73). Based on how one is socialised, the same treatment is perceived to be fair by one gender or race and unequal by another (Ngo, Foley, Wong \& Loi, 2003:227).

\section{Approaches to pay equity/inequity}

The approach to equal pay has, for over the longest period of time, been evolving and has shifted from the idea of similarity to the idea of similar worth, and from a woman-centeredness to an emphasis on the significance of gender or race (Khovera, 2012:14). It is hoped that pay equity is regarded as good governance that needs to sustain the employee retention in organisations (Adelekan \& Bussin, 2017:9).

\section{Racial and gender inequality}

The racial job segregation is the one most visible feature within the South African labour market. It manifests itself in a horizontal segregation between economic sectors and vertically between occupational categories, leaving African workers in less skilled and less remunerated activities (Rospabe, 2002:13). South African researchers and researchers across the globe have shown less interest in exploring racially based pay discrimination and have constantly researched gender-based pay inequity (Kray et al., 2001:942). Khovera (2012:47) and Barron (2003:635) attest that the behaviour in itself perpetuates the pay gap, as those excluded due to race are denied the opportunity for an increased perception on their monetary worth and bargaining power.

\section{Pay structures and pay scale levels per job/position}

Pay structure includes salary ranges, and each position title and level have a pay scale. Considering a supervisor position title, it will have a graded pay scale of task level 11 (T11) and the salary range will include a lower percentile (bottom range), a median percentile and an upper percentile (maximum) per month (Analytico, 2016). Inherently the pay structure is built with a range in order to allow the accommodation of various competency levels of incumbents aligned and supported by the market factors (Laubscher \& Gilfillan, 2015:28). Based on the above, differentiation is allowed if in line with the Employment Equity Regulations (Oliphant, 2015:13).

\section{Onus of proof}

Onus of proof is insufficient and ineffective to drive the employer's non-compliance behaviour to equal pay as evidenced by continued pay gaps for groups who discriminated against (Blau \& Khan, 2017:789). This follows continued research on and investigations into women's attributes that the universe uses to justify why they are paid less than men rather than researching why practitioners and line managers tasked with salary determination continue to make women remuneration offers that are less and lower than that of their male counterparts (Levy, 2015:1). The onus of proof has run its cause and based on challenges of equal value and pay transparency, the employee side of onus to proof needs to be relaxed.

\section{Equal pay implementation powers}

In South Africa, the commissioners and courts, through the Employment Equity Act, are able to make individual judgments and awards towards equal pay claims made against employers (Levy, 2015:2). The adjudication and the award provided by the Labour Court when a complainant is successful with an unfair discrimination claim may include any appropriate order regarded as just and equitable as provided for in Section 50(2) of the Employment Equity Act (Dube, 2017:7). This includes payment for damages such as lost benefits that resulted from this discrimination levied to the employee by the employer. Payment for compensation with regard to employee infringement of dignity caused by this discrimination and an order directing the employer to take steps to prevent the same unfair discrimination from occurring in the future in respect to other employees (Laubscher \& Gilfillan, 2015:40). 


\section{Application Complexities of Equal Pay}

Employers are confronted by challenging and conflicting roles. They need to put plans together that progressively reduce the pay gap over time; however, at the same time they may be faced with an individual claim that disregards the efforts already made to the overall employer plans to redress and eliminate unfair practices. Court cases that are successful against the employer for the organisation to embrace equal pay provide limited relief to the applicants (Dube, 2017:7). The situation thus perpetuates the pay gap.

The Department of Labour inadequately deals with the overall company non-compliance to equal pay and expects the company to address the discrepancy over time on its own accord (Scheepers, 2014:20). If salaries revealed disproportionate levels, the Department is unable to enforce the discrepancy. It should be acknowledged that internal processes may have changed to accommodate the massive salary disparities that the organisation is scheduled to address, and instead be compromised by an individual claim. Guidelines for good practice are open for interpretation by various users and continue to show imperfect understanding as to what employers need to do (Levy, 2015:2). Instead of assisting them, these guidelines frustrate users, making them doubtful.

The traditional rationale of pay structures that are aligned with the market position is becoming irrelevant if professional users find it difficult to apply the rationale (Levy, 2015:2). It includes the use of related experiences and/or tenure, as applicants who have been in the particular position for longer, should be disregarded as a justifiable factor because a new entrant might be able to deliver the job accurately within a limited time (Padayachie, 2015:12).

In the absence of practical tools and guidelines to guide human resources practitioners, the pay gap will persist or take a different form (Levy, 2015:2). Challenges mentioned include the use of marketrelated salary offers; competent people making audible requests, thus negotiating for increased offers. Lack of consistent application when dealing with a high number of employees; using previous salaries to then make offers that are just fine but could have been better, should the previous salary be kept out; and the natural human discriminatory behaviour all make up the equal pay gap (Padayachie, 2015:14). It should be better for newly established companies that are without a pay history. Employers are advised to conduct a careful analysis of the differences that exist among all employees, including gender, with the intend to put corrective action plans together in order to avoid the risk of having disputes and an unhappy workforce which could later damage the company image (Laubscher \& Gilfillan, 2015:54).

\section{Persistence of the Pay Gap}

The "us" and "them", employees and employers, men and women, whites and non-whites, separation and categorisation are the root causes of discrimination (Johnson, 2017:13), as these lead to domestication of own members or fellow persons, thus reducing their output. In doing so, employees discriminated against and paid less will end up costing the company more than they produce or offer to the company (Johnson, 2017:13). "Us" and "them" practices reaffirm the self by rejecting, degrading and discrediting others that are unlike oneself. It is, therefore, important to understand that putting two things together, "them" and "us", will benefit the country and the organisation if brought together by a purposefully driven culture (Johnson, 2017:13). The pay gap is, therefore, the result of "us" and "them" discrimination. 
Figure 1: Monthly earnings per profession

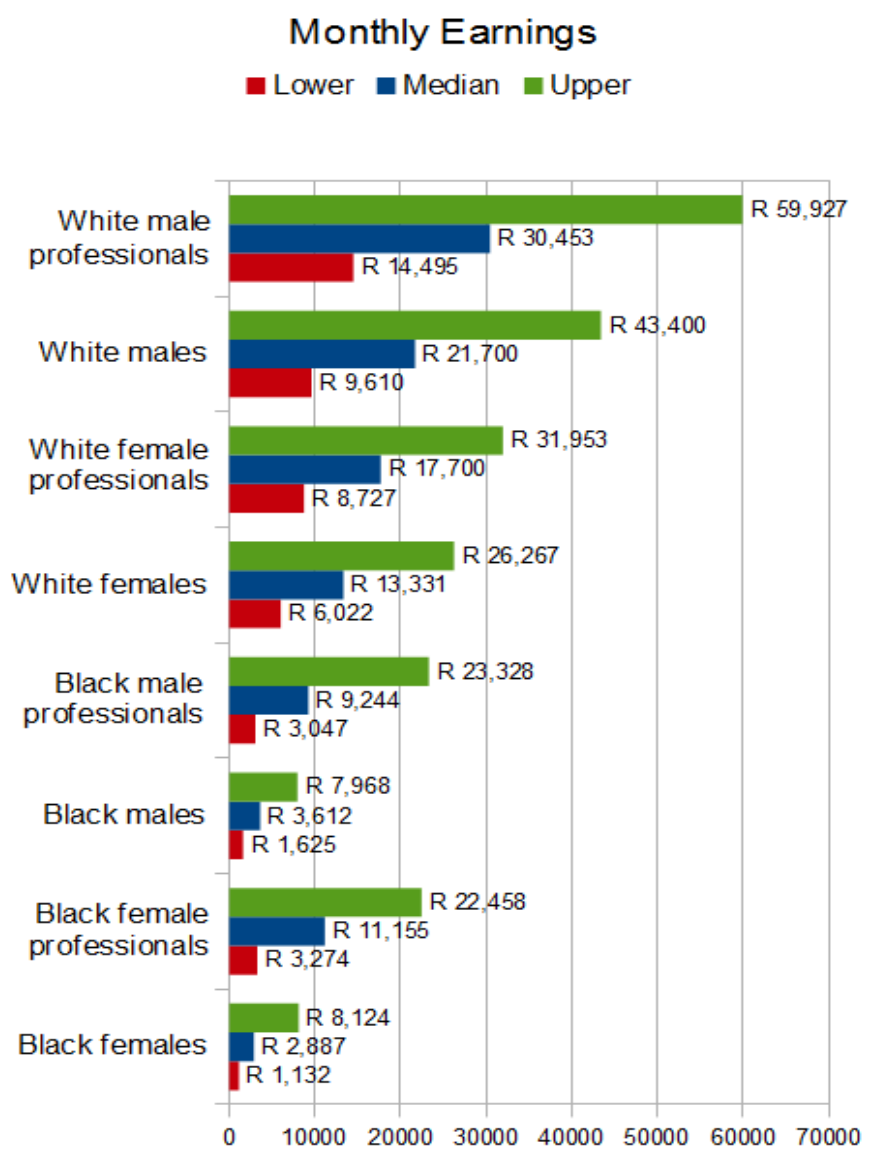

Source: Adapted from Analytico, 2019

In order to substantiate the South African version of the pay gap, Statistics South Africa (2017:4) estimate in their report that men earn a median salary of R3 500 per month compared to R2 700 per month in 2015. This report shows that African and Coloured women earn a median of R2 500 and R 2700 per month compared to Indian and white employees who earn a median of R6 000 and R10 000 respectively.

Figure 1 shows lower, median and upper percentiles for white male professionals and white males generally, white female professionals and white females generally, black males professionals and black males generally, and black female professionals and females generally. As equal pay provision permits that differentiation, Figure 1 is compressed due to employees being at the upper percentile, some at the median and others at the lower level.

In South Africa, factors that allow and justify the difference in pay (Oliphant, 2015:13) and thus regarded as fair include:

The individual seniority or length of service

Qualifications, abilities and competencies or the potential of doing the job

Performance, quality or quantity of work performed

If an employee is demoted without reducing his/her salary due to organisational

restructuring or legitimate reasons

Employees temporarily employed in a position

The existence of a shortage of a relevant skill

Any other relevant factor that is not unfairly discriminatory

It is, therefore, necessary to observe different salaries at appropriate percentiles as permissible by the South African law under the Employment Equity Regulations. The evidence, as indicated in the above 
figure, shows that salaries of white males are excessively higher than those of professional women and professional Africans, while unprofessional white males' salaries are higher than those of white female professionals, and white females, irrespective of professional level, outweigh the salaries of African men and African women. African male salaries almost match the salaries of African women.

The pay gap in modern America, as cited by Causevic (2018:741), was such that women received 59 cents for every dollar earned by men in 1960, 71 cents for every dollar man earned in 1990, 63 cents for African American women and 54 cents for Latinas in 1990. Further projections by Causevic (2018:741) are that, if the gap closed at the rate, it did between 1960 and 2015, then women would achieve pay equity by 2059, which is alarming. It confronts society with the unpleasant truth that pay equity is still just a slogan, far-fetched and unrealisable, even after 55 years of policy enactment.

The gender pay gap and pay inequity are unfortunately still a reality in South Africa (Boninelli, 2015:12). A collective effort by appropriate key stakeholders is required to turn this chronic situation around and achieve equal pay for all. Biltagy (2014:38) state that the Oaxaca-Blinder decomposition of gender wage gap demonstrated that the gap is due to discriminatory effects against women in the labour market.

Employers in various industries use salary scales that have a minimum and a maximum with a range of 56 percent between the two points. The minimum and maximum values of the scale have been benchmarked other external labour market positions and rates. The company's remuneration executive decides upon the minimum and maximum values per scale level, (Bosch, 2015:5). The range allows managers and remuneration advisors to position the employees' salary anywhere in between as deemed fit by their rationale, whether it is fair or unfair. According to Boninelli (2015:10) wage gaps are discovered at one or more levels of pay. Pay determination can be below the salary scale and is sometimes above the maximum of the scale. Observed, practised and experienced cultures, traditions and overt discrimination tend to create restrictive employment conditions for economic exclusion. Bussin and Nienaber (2015:13) are of the view that executives and board members rarely put this topic on the agenda, while sometimes too little attention and time are spent discussing equal pay and its negative implications.

\section{Research Methodology}

The research investigated the employer environment of a South African state-owned enterprise (SOE). For purposes of the research, the SOE were called ZYD so that the company name remains anonymous, as agreed to with the company.

\section{Research Approach}

The study has employed an inductive theory development approach in that participants' experiences and perceptions about equal pay were observed at grass roots level, followed by an identification of patterns from these observations, as well as the creation of tentative themes and theories which lead to theory development (Saunders et al., 2012:145). The employed inductive approach is a bottom-up process allowing ideas, concepts and themes to emerge from the interview data (Doody \& Noonan, 2013:29). This approach confirms the logic of generating untested conclusions.

\section{Research Philosophy}

The development of a new theory through the pursued research on equal pay were influenced by epistemological assumptions of the researcher with regard to human knowledge assumptions. The interpretivist research philosophy was appropriate to the research therefore, adopted to shape and deliver a methodology and strategy, as well as data collection and data analysis that fit together.

\section{Research Paradigms}

The findings were reflective of subjective experiences and perceptions gathered at the place of work with various interactions between individuals. In establishing how the employer ZYD has implemented equal pay, no one objective point of view about the truth was appropriate to provide a representative view about the world within enormities of people.

Research Methods

The research study involves an empirical investigation in response to research objectives and questions. Quantitative research question in ZYD and secondary data has been used (Saunders et al., 
2012:183). It involved exploring employer's records regarding employees who have been involved in the income disparity exercise, which involved verified data to be analysed.

Regarding the qualitative research questions, a purposive homogenous sampling process of collecting data, were used to select participants. The rationale behind the choice was that the homogenous sample possessed requisite knowledge and experience on the researched topic (Parse, 2001:59). A semi-structured interview guide used to gather rich descriptions, ideas, reasons, explanations and experiences in the participants' own words held at the employer site. Interview questions, as indicated in Appendix A, were generated, and tested with two senior managers in the Organisational Development Department of ZYD. The senior managers were involved in and knowledgeable about phrasing questions, as they were responsible for the employer engagement surveys. The research questions were revised taking into account the senior managers' inputs before being used by the purposive homogenous sample.

Sample procedure and size

Purposive sampling or selective judgemental sampling was accepted as the alternative to random sampling research approach (Saunders et al., 2012:301). It was well suited for a research study that requires the rich, diverse and complex knowledge and experiences on sociological units of measure from insiders in order to gain an in-depth understanding of equal pay from them (Saunders et al., 2012:297).

Data collection

Numeric financial variables were the units of analysis appropriate to the numeric research questions (Saunders et al., 2012:166). The data collection process involved archival spreadsheets comprising secondary data that the employer had stored privately. Permission to access and use the data was obtained. Data was made available, retrieved, verified and analysed. The researcher self-administered the spreadsheet.

Data analysis

Working with and organising data, breaking it into manageable units, synthesising data in order to explore patterns, uncovering important information that relates to the research objective and questions.

Ethical considerations

Permission to access the premises of the state-owned enterprise ZYD and to use the data was granted. Anonymity and privacy of participants as well as of the employer and the information were upheld. Participation in the research was free and voluntary, and participants could withdraw at any time without any negative impact on them.

Ethical clearance was obtained from the employer and the University of Johannesburg before engaging in the research. Due to the sensitivity of the research topic the names of the participants and the transcripts had only been made available to the research team. In some instances, participants might have taken a stance to refuse to speak negatively about the employer. As total anonymity was impossible to achieve when using face-to-face interviews and telephone interviews, the data were stored and reported in a manner that the sources were unidentifiable, and where it was identifiable, only the research team had access to those sources.

Major Findings

Legislation alone cannot make equal pay for work of equal value work possible in South Africa. The labour courts can instruct employers to adjust individuals' pay in comparison to the comparator or company-wide salary adjustments if salary discrepancies are observed. However, the labour courts cannot take over the role of wage determination where employers fail to comply with non-conformance. This requires that the company display a business will to implement this provision (Hlongwane, 2007). The evidence, as observed in the gender-based pay gap, is proof that without the company will implement equal pay, the pay gap will persist.

Collective bargaining provides an approach that mitigates for equal pay, as benefits and salary increases are negotiated for every bargaining unit employee. This is in support of the equal pay, provided the base salary is the same. Employers and trade unions should make this aspect an agenda item and discuss it with an open mind, since organisations are continuously challenged with inadequate funding. 
Using the thematic analysis found in the interpretative phenomenological analysis initially proved to be difficult. However, through the reiterations, interconnectedness and iterative nature of the analysis methods, an appropriate understanding prevailed, allowing adequate sense making, refinement and grounded interpretations of participants' voices.

The study confirms that implementing equal pay has a financial implication attached to it, insignificant as it is. Uncoordinated confirmations for promoting equal pay exist. Lack of a comprehensive approach to equal pay encompasses the majority concerns.

The relationship of the central themes identified in the equal pay study shows how important it is for the organisation to have all essential pillars in place and in sync with one another, which lagged in this case. With the essential pillars in place and in sync, a robust pay equity system/model, which is supported by policy, will be leveraged and initiated as a business imperative, promoting open communication and empowerment about equal pay (Bradshaw, et al., 2017:3).

\section{Recommendations for Future Research}

The results and comments of this research highlight the need for further areas of intervention. Further research in other employer environments should be undertaken to understand the intricacies involved in equal pay, and to make South Africa's labour market more inclusive and equitable. The various employer findings may then provide a platform for comparison, with the intention of adopting workable solutions. Studying the institutional context where pay is determined, policy developed and the implementation takes place was very important (Sandberg, 2016:46) as it was evidenced in this study. This is so as understanding the context shapes the future better (Sandberg, 2016:46). It is recommended that further research be conducted in future and in ZYD with improved economic stability, as this will likely produce different responses and findings. A different context in ZYD following the sharing of these research findings could provide different, suitable and usable findings. Future research studies should be conducted in other state-owned enterprises in order to provide findings for different context, as this study was limited to one state-owned enterprise.

South African researchers and researchers across the globe have shown little interest to explore the racial pay discrimination situation; they have constantly researched gender-based pay inequity instead. This should be reason enough to have future research studies focusing on pay equity irrespective of race, gender or disability.

The study was considerate that the topic researched was sensitive to employees, trade unions and the employer. In order to access a sample from every employee in the organisation, a quantitative data collection method such as a survey questionnaire could have been appropriate, and if the emphasis was to obtain an appropriate representation of the sample. Such a sample would also require more time to conduct the research. Disregarding the sensitivity would have led to disruptive responses detrimental to the employer, which would have been disapproved.

Acknowledgement was made that research rarely delivers unquestionable results and that total researcher objectivity was never possible, and that the adopted interpretive and pragmatist paradigms have diversity and subjectivity at the core, with no certainty or acceptable theory (Saunders et al., 2012:202,7

\section{Final Conclusions}

It is essential for employers to have a robust system in place to analyse and provide pay information as required by various relevant stakeholders, primarily to empower managers. The results and findings of this study can be used in guiding employers' efforts on pay strategies, which, in its totality, will focus on all pillars of equal pay.

The removal of racial and gender discrimination in South Africa involves the participation of employers, trade unions and the government through legislation. A coordinated effort is required to bring together all stakeholders to make pay equity a reality, acknowledging pay equality. Closing the pay gab is almost a lifelong action that requires unwavering commitment as environmental challenges escalate and constantly change in the workplace. Understanding the dynamics of equal pay is crucial for all stakeholders, of special relevance to practitioners and policy developers, as it will focus future deliberations for pay inequity (Bradshaw, 2017:3). 


\section{References}

Adelekan, A.M. \& Bussin, M.H.R. 2018. Gender pay gap in salary bands among employees in the formal sector of South Africa. SA Journal of Human Resource Management/SA, 1-10. DOI:10.4102/sajhrm.v16io.1018

Analytico. 2016. Available from: http://www.analyticohr.com/

Arulampalam, W., Booth, A. \& Bryan, M. 2007. Is there a glass ceiling over Europe? Exploring the gender pay gap across the wage's distribution. Industrial and Labour Relations Review, 60(2):163-186.

Attride-Stirling, J. 2001. Thematic networks: An analytic tool for qualitative research. London: Sage.

Bakari, Z.A. 2014. Pay equality: Reassessing the gender pay gap, a comparable analysis of South Africa, India and Tanzania. Unpublished master's dissertation. Cape Town: University of Cape Town. 1-70.

Barron, L. 2003. Ask and you shall receive. Gender differences in negotiators' beliefs about requests for higher salary. Human Relations, 56:635-662.

Barrick, G. 2018. The gender pay gap: Will the tide finally turn? People Dynamics, April-June 2018:37-38.

Bell, E., Bryman, A. \& Harley, B. 2018. Business research methods. 5th ed. New York: Oxford University Press.

Blau, F.D. \& Kahn, 1.M. 2007. The gender pay gap: Have women gone as far as they can? Academy of Management Perspectives, 21(1):7-23.

Blau, F.D. \& Kahn, 1.M. 2017. The gender wage gap: The extent, trends, and explanations. Journal of Economic Literature, 55(3):789-865.

Boninelli, I. 2015. The Gender pay audit: Practical steps for multi-national and local companies. In A. Bosch (Ed.). SABPP Women's Report 2015: Equal Pay for Equal Value, 7-12. Parktown, South Africa: SABPP.

Bosch, A. 2015. Reasons for the gender pay gap: What HR practitioners should know. In A. Bosch (Ed.). SABPP Women's Report 2015: Equal Pay for Equal Value, 3-6. Parktown, South Africa: SABPP.

Bradshaw, C., Atkinson, S. \& Doody, W. 2017. Employing a qualitative description approach in health care research. Global Qualitative Nursing Research, 4:1-8. DOI:10.1177/2333393617742282

Brown, S.L. 2017. Negotiating around the Equal Pay Act: Use of the "factor other than sex" defense to escape liability. Ohio State Law Journal, 78(2):472-502.

Bryman, A. \& Bell, E. 2015. Business research methods. $4^{\text {th }}$ ed. New York: Oxford University Press.

Buhalis, D. 2001. Tourism in Greece: Strategic Analysis and Challenges. Current Issues in Tourism, 4(5):440-480.

Bussin, M.H.R. \& Nienaber, R. 2015. The gender pay gap: A boardroom perspective. In A. Bosch (Ed.). SABPP Women's Report 2015: Equal Pay for Equal Value, 13-17. Parktown, South Africa: SABPP.

Bussin, M.H.R. \& Smit, E. 2015. Understand equal pay for work of equal value. Finance, Hot Button, 28-29. Available from: https://www.hrfuture.net

De Wet, R. 2018. Equal pay for work of equal value. Labour Elite, 1-84. August.

Dube, T. 2017. A critical analysis of the equal pay for equal work or work of equal value provision as it relates to the South African labour market. Unpublished master's dissertation. Pietermaritzburg Campus: University of KwaZuluNatal. 1-43.

Ebrahim, S. 2016. Equal pay for work of equal value in terms of the employment equity Act 55 of 1998: Lessons from the International Labour Organization and the United Kingdom. Potchefstroom Electronic Law Journal, 2016(19):127. DOI:10.17159/17273781/2016/v19n0a1230

Ebrahim, S. 2017. Equal pay in terms of the Employment Equity Act: The role of seniority, collective agreements and good industrial relations. Pioneer Foods (Pty) Ltd v Workers against Regression. Potchefstroom Electronic Law Journal 2017(20).1-18 ZALCCT14. DOI:10.17159/17273781/2017/v20i0a1524

Figart, D.M. 2000. Equal pay for equal work: The role of a job evaluation in an evolving social norm. Journal of Economic Issues, XXIV(1):1-19.

Freidenvall, L. \& Dahlerup, D. 2009. Minority women's organisations and diverse claims for representation: Intersections of gender and ethnicity. ECPR General Conference in Potsdam, Germany, September: 10-12.

Khoreva, V. 2012. Gender inequality, gender pay gap and pay inequality: Perceptions and reactions in Finnish society and workplaces. Hanken School of Economics, 247:1-150.

Laubscher, T. \& Gilfillan, N. 2015. Equal pay for work of equal value. A South African perspective:1-53. https://www.saslaw.org.za or https:// docplayer.net/31027450

Levy, A. 2015. Pay equality seminar: Pay equality to challenge SA bosses. Sage HR \& Payroll. July:1-3. Available from: https://www.iol.co.za/business-report/pay-equality-to-challenge-sa-bosses-1892305

Lombardo, E., Meier, P. \& Verloo, M. 2009. Discursive dynamics in gender equality politics: What about feminist taboos? European Journal of Women's Studies, 17(20):105-123.

Makhunga, B.M. 2015. Equal pay for work of equal value: What are the implications and is it really new? Human resources matter. Presentation at SARA Awards:1-25. Available from:

http://www.sara.co.za/sara/file\%20storage/Documents/presentations/Equal\%20Pay\%204\%20Work\%20of\%20Equa $1 \% 20$ Value.pdf 
Oliphant, M.N. 2015. Code of good practice on equal pay. Remuneration for work of equal value. Government Gazette Notice 37873, 1-9. Available from: http:/ / www.gpwonline.co.za

Padayachie, K.M. 2015. Education and the gender wage gap in South Africa. Unpublished master's dissertation. Durban: University of KwaZulu-Natal. 1-59.

Pienaar, H. 2015. The meaning of equal value in terms of pay. In A. Bosch (Ed.). SABPP Women's Report 2015: Equal Pay for Equal Value, 18-22. Parktown, South Africa: SABPP.

Pregnolato, M., Bussin, M.H.R. \& Schlechter, A.F. 2017. Total rewards that retain: A study of demographic preferences. South African Journal of Human Resource Management, 15(a804):1-10. DOI:10.4102/sajhrm.v15.804

Roberts, T. 2013. Understanding the research methodology of interpretive phenomenological analysis. British Journal of Midwifery, 21(3):215-218.

Rospabe, S. 2002. How did labour market evolve after the end of apartheid? An analysis of the evolution of hiring, occupational and wage discrimination in South Africa between 1993 and 1999. South African Journal of Economics, 70(1):185-217.

Sandberg, P. 2016. The politics of gender pay equity: Policy mechanisms, institutionalised undervaluation, and non-decision making. Published doctoral thesis. Helsinki, Finland: Hanken University:1-138.

Scheepers, J. 2014. Equal pay for work of equal value: How do we get there? The South African Labour Guide, 1-20. Available from: https://www.labourguide.co.za/equal-pay-for-work-of-equal-value

South Africa. 2018. Basic Conditions of Employment Act 7 of 2018. Pretoria: Government Printer.

South Africa. 1996. Constitution of the Republic of South Africa. Pretoria: Government Printer.

South Africa. 1998. Employment Equity Act 55 of 1998. Pretoria: Government Printer.

South Africa. 1998. Employment Equity Act 55 of 1998 as amended. Code of good practice on equal pay/Remuneration for work of equal value. Government Gazette, 600(38837). Pretoria: Government Printer.

South Africa. 2014. Employment Equity Regulations GN R595 in GG 37873 of 1 August 2014. EER.

South Africa. Labour Relations Act 66 of 1995. Pretoria: Government Printer.

South Africa. Department of Statistics. 2017. I know the home, I understand:1-238. Pretoria: Department of Statistics.constitu

South African Human Rights Commission. 2016. Research brief on race and equality in South Africa 2013-2017. Available from

https://www.sahrc.org.za/home/21/files/RESEARCH\%20BRIEF\%20ON\%20RACE\%20AND\%20EQUALITY\%20IN \%20SOUTH\%20AFRICA\%202013\%20TO\%202017.pdf:1-23.

Steyn, R. \& Jackson, L. 2015. Gender-based discrimination in South Africa: A quantitative analysis of fairness of remuneration. South African Journal of Economic and Management Sciences, 18(2):190-205. DOI:10.17159/2222$3436 / 2015 / v 18 n 2 a 4$

Suls, J., Martin, R. \& Wheeler, L. 2000. Social comparison: Why, with whom and with what effect? Current Directions in Psychological Science, 11(5):159-163.

Sullivan-Bolyai, S., Bova, C. \& Harper, D. 2005. Developing and refining interventions in persons with health disparities: The use of a qualitative description. Nursing Outlook, 53:127-133.

Tshetlo, S. 2015. Equal pay in South Africa: How does equal pay legislation work in South Africa? Available from: https://www.cliffedekkerhofmeyr.com/export/sites/cdh/en/practice-areas/downloads/Employment-EqualPay-Brochure.pdf: 1-3.

Tufarolo, M.A. 2016. You haven't come a long way, baby: The courts' inability to eliminate the gender wage gap fiftytwo years after the passage of the Equal Pay Act. Journal of Gender, Social Policy and the Law, 24(2):305-337.

Van Heerden, A. 2015. Pay equality to challenge SA bosses. Business Report. July:1-3 Available from: https://www.iol.co.za/business-report/ pay-equality-to-challenge-sa-bosses-1892305.

Watkins, T.A. 2019. The ghost of salary past: Why salary history inquiries perpetuate the gender pay gap and should be ousted as a factor other than sex. Minnesota Law Review, 103(2):1041-1088. 